ISSN: 2302-8556

\title{
Pengaruh Pelatihan, Kemampuan Teknik Pemakai Sistem Informasi Akuntansi dan Dukungan Manajemen Puncak Pada Kinerja Individual
}

\author{
Ni Made Ayu Nita Adiyantari ${ }^{1}$ \\ I Ketut Yadnyana ${ }^{2}$ \\ ${ }^{1,2}$ Fakultas Ekonomi dan Bisnis Universitas Udayana (Unud), Bali, Indonesia \\ e-mail: nitaadiyantari@gmail.com
}

\begin{abstract}
ABSTRAK
Karyawan yang bekerja dalam suatu perusahaan diharapkan mampu menyelesaikan tugasnya dan menghasilkan informasi secara tepat waktu, akurat, serta dapat dipercaya. Faktor-faktor yang dapat mempengaruhi kinerja masing-masing individu harus selalu diperhatikan oleh perusahaan guna tercapainya kinerja individual yang optimal. Penelitian ini dilakukan pada PT. BPR Bank Kertiawan. Teknik penentuan sampel yang digunakan adalah teknik sampel jenuh. Jumlah responden yang digunakan adalah sebanyak 80 orang karyawan. Teknik analisis yang digunakan adalah analisis regresi linier berganda. Hasil penelitian ini menunjukkan bahwa pelatihan, kemampuan teknik pemakai SIA, dan dukungan manajemen puncak berpengaruh positif dan signifikan pada kinerja individual di PT. BPR Bank kertiawan.

Kata kunci : Pelatihan, dukungan manajemen puncak, kemampuan teknik pemakai SIA , kinerja individual
\end{abstract}

\begin{abstract}
Employees who work in companies are expected to do their responsibility and gives accurate and reliable information on time. Factors that can affect the performance of each individual must always be considered by the company in order to achieve optimal individual performance. This research was conducted at PT. BPR Bank Kertiawan. The sampling technique used is a saturated sample technique. The number of respondents used is 80 employees. This study use multiple linear regression analysis as the analysis technique. The results of this study indicate that training, the ability to use SIA techniques, and top management support have a positive and significant influence on individual performance at PT. BPR Bank Kertiawan

Keywords : Training, top management support, AIS user technical capabilities, individual performance
\end{abstract}

\section{PENDAHULUAN}

Peningkatan kinerja BPR dapat dilakukan dengan cara menyediakan fasilitas untuk karyawan agar mereka dapat menyelesaikan pekerjaan dengan lebih cepat dan efisien, salah satunya yaitu dengan menggunakan sistem informasi akuntansi. 
Ni Made Ayu Nita Adityantari dan I Ketut Yadnyana. Pengaruh ...

PT. BPR Bank Kertiawan merupakan salah satu BPR yang saat ini sedang berkembang di provinsi Bali dan sudah memiliki 3 (tiga) buah kantor cabang serta 3 (tiga) buah kantor kas, yang tersebar di Kabupaten Tabanan, Badung, Gianyar, dan Kota Denpasar. Sejak tahun 2015 BPR Kertiawan mengganti sistem yang digunakan dengan sistem yang lebih modern yaitu aplikasi go-banking yang merupakan suatu sistem informasi bank (core banking) terintegrasi antara bagian yang satu dengan lainnya serta berfungsi untuk membantu melakukan pencatatan transaksi bank sampai dengan menghasilkan laporan, sudah dikembangkan dapat terhubung secara online antar kantor.

Peran yang dijalani oleh PT. BPR Bank Kertiawan sama seperti BPR pada umumnya, salah satunya yaitu menyalurkan kredit untuk UMKM. Peran ini dilaksanakan oleh bagian Accounting Officer (AO). Jumlah kredit BPR Kertiawan tahun 2013-2017 dapat dilihat pada tabel 1 berikut ini.

Tabel 1.

Perkembangan Kredit PT. BPR Bank Kertiawan Tahun 2013-2017

\begin{tabular}{cccc}
\hline No & Tahun & $\begin{array}{c}\text { Total Kredit (dalam } \\
\text { ribuan rupiah) }\end{array}$ & $\begin{array}{c}\text { Pertumbuhan } \\
(\%)\end{array}$ \\
\hline 1 & 2013 & 110.537 .475 & $-0,96$ \\
2 & 2014 & 147.220 .690 & 33,19 \\
3 & 2015 & 149.137 .296 & 1,30 \\
4 & 2016 & 182.829 .011 & 22,59 \\
5 & 2017 & 211.558 .383 & 15,71 \\
\hline \multicolumn{4}{c}{ Rata-Rata } \\
\hline
\end{tabular}

Ditampilkan pada tabel 1 bahwa rata-rata kredit BPR Kertiawan adalah 160.256.571 dan rata-rata pertumbuhan sebesar 14,37\%. Walaupun BPR Kertiawan memiliki rata-rata pertumbuhan yang positif, namun lima tahun terakhir pertumbuhan kreditnya berfluktuasi. 
Kinerja individu sangat mempengaruhi keberhasilan sebuah perusahaan, dan individu diharapkan dapat menyelesaikan tugasnya tepat waktu dengan sistem yang ada. Menurut Arsiningsih, Diatmika, \& Darmawan (2015) peningkatan kinerja perusahaan bergantung pada bagaimana kinerja karyawan dari perusahaan tersebut.

Pelatihan dapat dikatakan berpengaruh karena semakin sering seseorang melakukan pelatihan maka akan semakin banyak memiliki pengetahuan mengenai sistem yang digunakan. Menurut Simamora (2007), pelatihan yaitu kegiatan untuk meningkatkan kemampuan maupun sikap individu.

Rouibah, Hamdy, \& Al-Enezi (2009) dalam penelitiannya mengenai hubungan antara ketersediaan pelatihan terhadap kepuasan pengguna, menemukan bahwa ketersediaan program pelatihan berpengaruh poistif terhadap kinerja individu. Berbeda dengan hasil penelitian Komara (2005), yang mendapatkan bahwa program pelatihan tidak berpengaruh terhadap kinerja sistem informasi.

Zein (2012) dalam penelitiannya menemukan bahwa kemampuan teknik pengguna SIA memiliki pengaruh positif pada kinerja. Hasil ini didukung oleh penelitian Alannita \& Suaryana (2014) Artha (2016) dan Sarastini \& Suardikha (2017). Dalam penelitiannya, Berbeda halnya dengan hasil penelitian Bunga (2014), yang menemukan bahwa tidak adanya pengaruh kemempuan teknik personal terhadap kinerja pemakai SIA. 
Ni Made Ayu Nita Adityantari dan I Ketut Yadnyana. Pengaruh ...

Dukungan manajemen puncak merupakan faktor penting untuk membantu keberhasilan manajer operasional untuk melaksanakan sistem informasi akuntansi. Jika tidak, maka implementasi sistem informasi akan gagal. Hasil penelitian Lee, Kozar, \& Larsen, (2003) dan Wirawan \& Suardikha (2016) menunjukkan bahwa dukungan manajemen berpengaruh signifikan terhadap penggunaan sistem informasi akuntansi. Berbeda dengan hasil penelitian Dunggio (2015), yang menyatakan bahwa dukungan manajemen puncak tidak berpengaruh terhadap kinerja pemakai SIA.

Penelitian ini menggunakan Teori TAM dan Teori Keyakinan Diri, Teori TAM merupakan suatu teori yang memuat model tentang sikap individu dalam menerima dan menggunakan teknologi. Dalam teori ini disebutkan perilaku personal dipengaruhi oleh dua hal dalam menggunakan dan menerima teknologi, yaitu usefulness atau kemanfaatan dan ease of use atau kemudahan penggunaan (Surendran, 2015). Menurut Petersen dalam Wirawan \& Suardikha (2016), teori ini menekankan pada kepercayaan terhadap diri sendiri. Produktivitas dapat dipengaruhi oleh tingkat keyakinan diri. Seseorang dengan tingkat keyakinan terhadap dirinya yang rendah memiliki kinerja yang lebih rendah dari kemampuan sebenarnya dan tidak memiliki motivasi untuk bekerja lebih baik.

Menurut Mulyadi (2016), sistem adalah suatu jaringan prosedur yang dibuat menurut pola yang terpadu untuk melaksanakan kegiatan pokok perusahaan. Menurut Romney \& Steinbart (2014;4) informasi (information) adalah data yang telah dikelola dan diproses untuk memberikan arti dan memperbaiki proses pengambilan keputusan. Bodnar \& Hopwood (2006), 
menyatakan bahwa sistem informasi merupakan penggunaan teknologi komputer oleh organisasi untuk memberikan informasi bagi pengguna serta pihak-pihak yang memerlukan.

Proses pengajaran dan pembentukan sikap kaaryawan agar semakin handal serta sesuai standar yang ditetapkan merupakan pelatihan kerja (Mangkuprawira, 2003;135). Terdapat lima jenis Training atau pelatihan sumber daya manusia yaitu (Sutadji \& Hariyanti, 2016) Skill Training atau pelatihan keterampilan, Retraining atau pelatihan kembali, Cross Functional Training atau pelatihan lintas fungsional, Creativity Training atau pelatihan kreativitas, dan Team Training atau pelatihan tim.

Robbins, DeCenzo, \& Coulter (2008) menyatakan kemampuan yaitu bagaimana seseorang dalam melakukan tugas. Kemampuan teknis pemakai sistem informasi dapat dibagi menjadi tiga hal yaitu pertama adalah pemakai sistem informasi akuntansi memiliki pengetahuan dan pemahaman mengenai sistem informasi akuntansi dan tugas dari pekerjaannya (knowledge), yang kedua adalah memiliki kemampuan dalam menjalankan SIA yang ada (ability), keahlian (skill), keahlian dalam pekerjaan yang menjadi tanggung jawab, keahlian dalam mengekspresikan kebutuhan-kebutuhan dalam pekerjaan.

Dukungan manajemen menurut Mooney, Mahoney, \& Wixom (2008) adalah bagaimana manajemen terlibat dalam pelaksanaan sistem informasi serta bagaimana manajemen memberikan strategi pengembangan untuk sistem informasi yang akan diterapkan. 
Ni Made Ayu Nita Adityantari dan I Ketut Yadnyana. Pengaruh ...

Kinerja individual karyawan adalah suatu kondisi yang harus diketahui dan dikonfirmasikan kepada pihak yang berkepentingan untuk mengetahui tingkat pencapaian tujuan suatu organisasi (Ochoti, Maronga, Muathe, Nyabwanga, \& Ronoh, 2012).

UU No. 10 Tahun 1998 mengatur mengenai Bank Perkreditan Rakyat. Dijelaskan dalam undang-undang bahwa BPR menjalankan kegiatan perbankan sesuai dengan aturan BI dan tidak memberikan jasa dalam lalulintas pembayaran.

Rouibah et al. (2009) menggunakan teori TAM dalam penelitiannya mengenai pengaruh ketersediaan pelatihan terhadap kepuasan pelanggan. Dalam penelitian yang dilakukan oleh Dwijayanthi \& Dharmadiaksa (2013) dan Medina, Jiménez, Mora, \& Ábrego (2014) ditemukan bahwa pelatihan memiliki pengaruh positif terhadap kinerja individu pengguna SIA. Maka rumusan hipotesis satu adalah:

$\mathrm{H}_{1}$ : Pelatihan berpengaruh positif pada kinerja individual.

Hasil penelitian Artha (2016) menemukan bahwa kemampuan teknik pemakai SIA memiliki pengaruh yang positif pada kinerja individual karyawan. Penelitian Alannita \& Suaryana (2014) dan Widyasari \& Suardikha (2015) juga menemukan bahwa kemampuan teknik pemakai sistem informasi akuntansi berpengaruh positif pada kinerja individual karyawan. Hal tersebut sejalan dengan penelitian Zaim, Yasar, \& Omer Faruk Unal (2013), dalam penelitiannya menemukan bahwa kemempuan teknik personal memiliki hubungan yang positif pada kinerja. Maka rumusan hipotesis dua dalam penelitian ini adalah:

$\mathrm{H}_{2}$ : Kemampuan teknik pemakai SIA berpengaruh positif pada kinerja individual. 
Hasil penelitian Lee et al. (2003) menunjukkan bahwa dukungan manajemen berpengaruh signifikan terhadap penggunaan sistem informasi akuntansi. Penelitian tersebut sejalan dengan penelitian Widyasari \& Suardikha (2015) dan Wirawan \& Suardikha (2016) yang menemukan bahwa dukungan manajemen puncak berpengaruh positif terhadap kinerja individual. Maka rumusan hipotesis tiga dalam penelitian ini adalah:

$\mathrm{H}_{3}$ : Dukungan manajemen puncak berpengaruh positif pada kinerja individual.

\section{METODE PENELITIAN}

Penelitian ini menggunakan pendekatan kuantitatif berbentuk asosiatif. Penelitian ini dilakukan pada PT. BPR Bank Kertiawan yang berlokasi di Bali. Lokasi ini dipilih karena adanya perkembangan usaha berskala mikro, kecil dan menengah (UMKM) yang menggunakan Bank Perkreditan Rakyat sebagai tempat simpan pinjam. PT. BPR Bank Kertiawan merupakan salah satu BPR yang banyak digunakan oleh masyarakat sebagai tempat simpan pinjam. Objek dalam penelitian ini adalah kinerja individual karyawan yang menggunakan sistem informasi akuntansi pada PT. BPR Bank Kertiawan.

Menurut Wilkinson \& Cerrulo (2000), pelatihan yang diberikan kepada karyawan sangat dibutuhkan dimana pelatihan tersebut diberikan agar karyawan lebih terampil dalam menggunakan sistem baru, sehingga akan memberikan keuntungan bagi para karyawan dalam menjalankan kegiatan operasional perusahaan. Menurut Kendall (2003) dalam Wulandari (2016) terdapat beberapa indikator yang digunakan untuk mengukur program pelatihan, yaitu Menetapkan sasaran yang jelas dan terukur, menggunakan metode latihan yang tepat, 
Ni Made Ayu Nita Adityantari dan I Ketut Yadnyana. Pengaruh ...

mempersiapkan materi pelatihan yang mudah dimengerti, pelatihan memberikan keuntungan, dan pelatihan diberikan oleh tenaga ahli.

Menurut Fitri (2008) dan Wirawan \& Suardikha (2016) kemampuan teknik pemakai diukur menggunakan lima indikator, yaitu pengetahuan mengenai sistem informasi, mampu menjalankan SIA, jenjang pendidikan pemakai sistem informasi, penempatan, dan pengetahuan mengenai tugas.

Menurut Hendra, Setiawanta, \& Septriana (2014) dan Wirawan \& Suardikha (2016) variabel dukungan manajemen puncak dapat diukur menggunakan 5 (lima) indikator, yaitu penyediaan software, penyediaan energi dan alat-alat, pengadaan program pelatihan, memiliki harapan yang tinggi terhadap penggunaan sistem, dan evaluasi hasil.

Indikator yang digunakan untuk mengukur variabel kinerja individu menurut Wirawan \& Suardikha (2016) dan Sarastini \& Suardikha (2017) yaitu kuantitas kerja atau quantity, kualitas kerja atau quality, ketepatan waktu atau timeliness, pengawasan supervisor atau need for supervisor, dan pengaruh rekan kerja atau interpersonal impact. Populasi penelitian ini adalah karyawan PT. BPR Bank Kertiawan yang bekerja menggunakan SIA dan memiliki masa kerja minimal satu tahun yaitu sebanyak 80 orang karyawan.

Besarnya jumlah sampel yang didapat yaitu 80 orang karyawan. Pemilihan sampel ini telah mewakili populasi, dengan batas minimum sampel suatu penelitian adalah sebanyak 30 sampel. Tenik penentuan sampel yang digunakan dalam penelitian ini adalah teknik sampel jenuh yaitu seluruh anggota populasi digunakan sebagai sampel untuk menghasilkan generalisasi dengan kesalahan 
yang sangat kecil (Sugiyono, 2017;145). Jumlah responden yang akan dilibatkan sebagai sampel dalam penelitian ini adalah sebanyak 80 responden.

Data kuantitatif adalah jenis data yang digunakan dalam penelitian. Data kuantitatif yang dimaksud adalah jawaban dari responden yaitu berupa data skor nilai. Data primer yang digunakan dalam penelitian ini yaitu jawaban responden dari kuesioner yang disebar.

Kuesioner yang digunakan dalam penelitian ini merupakan kuesioner yang diadopsi dari beberapa penelitian terdahulu dan telah dimodifikasi. Kuisioner akan disebarkan secara langsung kepada responden, dengan mendatangi langsung ke lokasi penelitian yaitu kantor pusat, kantor cabang maupun kantor kas PT. BPR Bank Kertiawan. Hasil jawaban kemudian diukur dengan menggunakan skala likert yang dimulai dari poin 1 Sangat Tidak Setuju (STS), poin 2 Tidak Setuju (TS), poin 3 Kurang Setuju (KS), poin 4 Cukup Setuju (CS), poin 5 Setuju (S), dan poin 6 Sangat Setuju (SS). Selain kuisioner, peneliti juga menerakpak wawancara tidak terstruktur untuk menghindari salah tafsir dari pertanyaan kuisioner.

\section{HASIL DAN PEMBAHASAN}

Karyawan PT. BPR Bank Kertiawan merupakan responden peneilitian ini. Karyawan yang menjadi responden yaitu karyawan yang menggunakan sistem informasi akuntansi dalam melaksanakan tugas harian mereka yang meliputi, Audit Intern, Kepala Bagian Bisnis, Kepala Bagian Operasional, Kepala Bagian Non Operasional/PE Kepatuhan dan Manajemen Risiko, Kepala Cabang, Kepala 
Ni Made Ayu Nita Adityantari dan I Ketut Yadnyana. Pengaruh ...

Kantor Kas, Staff Accounting Officer (AO), Staff Marketing Dana, Staff Admin Bisnis, Staff Teller dan CS, Staff Accounting, dan Staff HRD. Berikut pada Tabel 2 dijabarkan mengenai data pengambilan dan pengembalian sampel.

Pada Tabel 2 dijabarkan bahwa kuisioner disebarkan pada 80 responden dan dikembalikan utuh dan lengkap sehingga dapat digunakan untuk analisis penelitian.

Tabel 2.

Data Pengambilan dan Pengembalian Sampel

\begin{tabular}{lc}
\hline Keterangan & Jumlah \\
\hline Kuesioner yang disebar & 80 \\
Kuesioner yang tidak dikembalikan & 0 \\
Kuesioner yang dikembalikan & 80 \\
Kuesioner yang gugur (tidak lengkap) & 0 \\
Kuesioner yang digunakan & 80 \\
Tingkat pengembalian (responden rate) & $100 \%$ \\
Tingkat pengembalian yang digunakan (useable responserate) & $100 \%$ \\
\hline Sumber: Data diolah, 2018
\end{tabular}

Karakteristik responden yang diteliti meliputi jenis kelamin, jabatan, tingkat pendidikan dan pengalaman menggunakan SIA. Berikut pada Tabel 3 dijabarkan rincian karakteristik responden penelitian.

Berikut dijelaskan mengenai karakteristik responden; Karyawan berjenis kelamin laki-laki sebanyak 36 Orang (45 persen) dan karyawan yang berjenis kelamin perempuan sebanyak 44 orang (55 persen). Pengurus PT. BPR Bank Kertiawan yang memiliki jabatan sebagai Audit Intern sebanyak 2 orang (2,50 persen), Kepala bagian Bisnis sebanyak 4 orang (5 persen), Kepala Bagian 
Operasional 4 orang (5 persen), Kepala Bagian Non Operasional/PE Kepatuhan dan Manajemen Risiko sebanyak 2 orang (2,50 persen), Kepala Cabang sebanyak 3 orang (3,75 persen), Kepala Kantor Kas sebanyak 3 orang (3,75 persen), Staff AO sebanyak 13 orang (16,25 persen), Staff Marketing Dana sebanyak 15 orang (18,75 persen), Staff Admin Bisnis sebanyak 11 orang (13,75 persen), Staff Teller dan CS sebanyak 16 orang (20 persen), Staff Accounting sebanyak 4 orang (5 persen), dan Staff HRD sebanyak 3,75 orang (3,75 persen).

Tabel 3.

Karakteristik Responden Penelitian

\begin{tabular}{|c|c|c|c|c|}
\hline No & Variabel & Klasifikasi & $\begin{array}{l}\text { Jumlah } \\
\text { (orang) }\end{array}$ & $\begin{array}{l}\text { Persentase } \\
\quad(\%)\end{array}$ \\
\hline \multirow{2}{*}{1} & \multirow{2}{*}{ jenis Kelamin } & Laki-Laki & 36 & 45,00 \\
\hline & & Perempuan & 44 & 55,00 \\
\hline \multirow{14}{*}{2} & Jumlah & & 80 & 100 \\
\hline & \multirow{12}{*}{ Jabatan } & Audit Intern & 2 & 2,50 \\
\hline & & Kabag. Bisnis & 4 & 5,00 \\
\hline & & Kabag. Operasional & 4 & 5,00 \\
\hline & & $\begin{array}{l}\text { Kabag. Non Operasional/PE Kepatuhan } \\
\text { dan Manajemen Risiko }\end{array}$ & 2 & 2,50 \\
\hline & & Kepala Cabang & 3 & 3,75 \\
\hline & & Kepala Kantor Kas & 3 & 3,75 \\
\hline & & Staff AO & 13 & 16,25 \\
\hline & & Staff Marketing Dana & 15 & 18,75 \\
\hline & & Staff Admin Bisnis & 11 & 13,75 \\
\hline & & Staff Teller dan CS & 16 & 20,00 \\
\hline & & Staff Accounting & 4 & 5,00 \\
\hline & & Staff HRD & 3 & 3,75 \\
\hline & \multirow[t]{2}{*}{ Jumlah } & & 80 & 100,00 \\
\hline \multirow{4}{*}{3} & & SMA/SMK & 19 & 23,75 \\
\hline & \multirow{3}{*}{$\begin{array}{c}\text { Tingkat } \\
\text { Pendidikan }\end{array}$} & D1/D2/D3 & 14 & 17,50 \\
\hline & & S1 & 46 & 57,50 \\
\hline & & $\mathrm{S} 2$ & 1 & 1,25 \\
\hline & Jumlah & & 80 & 100,00 \\
\hline \multirow{4}{*}{4} & \multirow{3}{*}{$\begin{array}{l}\text { Pengalaman } \\
\text { Menggunakan } \\
\text { SIA }\end{array}$} & $1-5$ tahun & 18 & 22,50 \\
\hline & & 6-10 tahun & 34 & 42,50 \\
\hline & & $>10$ tahun & 28 & 35,00 \\
\hline & Jumlah & & 80 & 100,00 \\
\hline
\end{tabular}


Ni Made Ayu Nita Adityantari dan I Ketut Yadnyana. Pengaruh ...

Karyawan dengan tingkat pendidikan SMA/SMK sebanyak 19 orang (23,75 persen), karyawan dengan tingkat pendidikan Diploma sebanyak 14 orang (17,50 persen), karyawan dengan tingkat pendidikan $\mathrm{S} 1$ sebanyak 46 orang $(57,50$ persen), dan karyawan dengan tingkat pendidikan S2 sebanyak 1 orang $(1,25$ persen).

Pengalaman menggunakan SIA digunakan sebagai indikator untuk mengetahui jangka waktu responden menggunakan SIA dalam bekerja. Sebanyak 18 orang (22,50 persen) memiliki pengalaman menggunakan SIA selama 1-5 tahun, sebanyak 34 orang (42,50 persen) memiliki pengalaman menggunakan SIA selama 6-10 tahun, dan 28 orang (35 persen) memiliki pengalaman menggunakan SIA selama $>10$ tahun.

Hasil statistik deskriptif pada penelitian ini dapat dilihat pada Tabel 4.

\begin{tabular}{llrrrr}
\multicolumn{5}{c}{ Tabel 4. } \\
Hasil Statistik Deskriptif & \\
\hline & N & Minimum & Maximum & Mean & $\begin{array}{c}\text { Std. } \\
\text { Deviation }\end{array}$ \\
\hline Pel & 80 & 3,00 & 6,00 & 4,9650 &, 71354 \\
Kem & 80 & 3,20 & 6,00 & 5,0500 &, 64710 \\
Dmp & 80 & 2,60 & 6,00 & 5,0675 &, 68395 \\
Kin & 80 & 3,40 & 5,80 & 5,0450 &, 60794 \\
Valid N (listwise) & 80 & & & & \\
\hline Sumber: Data diolah, 2018 & & & & &
\end{tabular}

Berdasarkan tabel 4 dapat dilihat bahwa variabel independen yang memiliki nilai rata-rata tertinggi yaitu variabel dukungan manajemen puncak (Dmp) dengan nilai 5,0675 yang menunjukkan bahwa dukungan manajemen puncak sudah baik namun belum maksimal, dan diikuti oleh variabel kemampuan teknik pemakai SIA (Kem) dan pelatihan (Pel) yaitu masing-masing sebesar 5,0500 dan 4,9650. 
Variabel yang memiliki nilai terendah dari seluruh variabel independen adalah variabel pelatihan dengan nilai rata-rata yaitu 4,9650 hal ini menunjukkan bahwa pelatihan masih memerlukan perhatian yang paling tinggi dibandingkan variabel lainnya.

Berdasarkan tabel 4 nilai minimum untuk variabel pelatihan (Pel) sebesar 3,00 dan nilai maksimum 6,00. Variabel pelatihan yang diukur dengan 5 item pernyataan dengan bantuan skala likert 6 poin memiliki nilai rata-rata sebesar 4,9650 dengan nilai standar deviasi sebesar 0,71354. Hal ini menunjukkan bahwa variabel pelatihan cukup baik dan telah mendekati baik, namun belum maksimal. Dari 5 item pernyataan, pernyataan nomor 1 yang memiliki nilai rata-rata terendah yang berarti bahwa pelatihan yang diberikan belum dapat memberikan gambaran yang jelas tentang penggunaan sistem.

Berdasarkan tabel 4 dapat dilihat nilai minimum dari jumlah skor jawaban responden untuk variabel kemampuan teknik pemakai sistem informasi akuntansi (Kem) sebesar 3,20 dan nilai maksimum 6,00. Variabel kemampuan teknik pemakai sistem informasi akuntansi memiliki nilai rata-rata sebesar 5,0500. Variabel kemampuan teknik pemakai SIA sudah baik namun belum maksimal. Dari 5 item pernyataan, pernyataan nomor 2 yang memiliki nilai rata-rata terendah yang berarti bahwa kemampuan teknik pemakai dalam menjalankan sistem informasi akuntansi yang ada masih belum maksimal.

Berdasarkan tabel 4 dapat dilihat nilai minimum dari jumlah skor jawaban responden untuk variabel dukungan manajemen puncak (Dmp) sebesar 2,60 dan nilai maksimum 6,00. Variabel dukungan manajemen puncak memiliki nilai rata- 
Ni Made Ayu Nita Adityantari dan I Ketut Yadnyana. Pengaruh ...

rata sebesar 5,0675 yang berarti variabel dukungan manajemen puncak sudah baik namun belum maksimal. Dari 5 item pernyataan, pernyataan nomor 3 yang memiliki nilai rata-rata terendah yang berarti bahwa dukungan melalui kegiatan pelatihan berkelanjutan untuk para pemakai SIA masih belum maksimal.

Berdasarkan tabel 4 dapat dilihat nilai minimum dari jumlah skor jawaban responden untuk variabel kinerja individual (Kin) sebesar 3,40 dan nilai maksimum 5,80. Variabel kinerja individual memiliki nilai rata-rata sebesar 5,0450 yang berarti variabel kinerja individual sudah baik namun belum maksimal. Dari 5 item pernyataan, pernyataan nomor 5 yang memiliki nilai ratarata terendah yang berarti bahwa dukungan dari rekan kerja dalam menyelesaikan pekerjaan menggunakan SIA masih belum maksimal.

Instrumen penelitian diuji dengan menggunakan uji validitas dan uji reliabilitas untuk menentukan apakah instrumen penelitian cukup handal dignakan dalam penelitian ini. Uji validitas dilakukan untuk mengetahui valid tidaknya pertanyaan-pertanyaan yang tercantum di dalam kuesioner dengan bantuan program SPSS. Valid berarti instrumen tersebut dapat digunakan untuk mengukur apa yang seharusnya diukur (Sugiyono, 2017;198). Suatu pertanyaan dalam kuesioner dikatakan valid jika nilai kolerasinya 0,3 ke atas (Sugiyono, 2017;204). Setiap pertanyaan untuk setiap variabel dalam kuisioner yang digunakan dalam penelitian ini memiliki skor total diatas 0,30 maka dapat dinyatakan valid dan layak untuk ddigunakan. 
Tabel 5.

Hasil Uji Reliabilitas

\begin{tabular}{lcc}
\hline \multicolumn{1}{c}{ Variabel } & Cronbach's & \\
\hline Pelatihan (Pel) & Alpha & Keterangan \\
Kemampuan Teknik Pemakai SIA (Kem) & 0,886 & Reliabel \\
Dukungan Manajemen Puncak (Dmp) & 0,837 & Reliabel \\
Kinerja Individual (Kin) & 0,855 & Reliabel \\
\hline
\end{tabular}

Sumber: Data diolah, 2018

Hasil uji reliabilitas untuk variabel pelatihan, kemampuan teknik pemakai SIA, dukungan manajemen puncak dan kinerja individual adalah sebagai berikut: 0,886;0,837; 0,855 dan 0,832 . Nilai Cronbach's Alpha seluruh variabel lebih besar dari 0,6 sehingga dapat dikatakan bahwa instrumen tersebut reliabel.

Hasil uji normalitas data dapat dilihat pada Tabel 6.

Tabel 6.

Hasil Uji Normalitas

\begin{tabular}{lc}
\hline & Unstandardized Residual \\
\hline $\mathrm{N}$ & 80 \\
Kolmogorov-Smirnov Z & 0,090 \\
Asymp. Sig. (2-tailed) & 0,168 \\
\hline \multicolumn{2}{c}{ Sumber: Data diolah, 2018 }
\end{tabular}

Hasil uji normalitas di atas menunjukkan koefisien Asymp. Sig. (2-tailed) sebesar 0,168 yang lebih besar dari 0,05. Hal ini berarti data dalam penelitian ini berdistribusi normal.

Hasil uji multikolinieritas disajikan pada Tabel 7. Berdasarkan tabel 7 dapat diketahui bahwa seluruh variabel menunjukkan nilai tolerance lebih dari 0,10 dan nilai VIF yang kurang dari 10. Hal ini mengidentifikasi bahwa dalam penelitian ini tidak terjadi gejala multikolinieritas. 
Tabel 7.

Hasil Uji Multikolinieritas

\begin{tabular}{lcc}
\hline \multicolumn{1}{c}{ Variabel } & Tolerance & VIF \\
\hline Pelatihan (Pel) & 0,296 & 3,383 \\
Kemampuan Teknik Pemakai SIA (Kem) & 0,276 & 3,626 \\
Dukungan Manajemen Puncak (Dmp) & 0,289 & 3,457 \\
\hline Sumber: Data diolah, 2018 & &
\end{tabular}

Pada Tabel 8 menunjukkan hasil heteroskedastisitas untuk penelitian ini. Tabel 8 menunjukkan bahwa seluruh variabel menunjukkan hasil signifikansi lebih dari 0,05 yang berarti bahwa tidak terdapat gejala heteroskedastisitas dalam penelitian ini.

Tabel 8.

Hasil Uji Heteroskedastisitas

\begin{tabular}{lcc}
\hline \multicolumn{1}{c}{ Variabel } & T & Sig. \\
\hline Pelatihan (Pel) & 0,684 & 0,496 \\
Kemampuan Teknik Pemakai SIA (Kem) & $-1,24$ & 0,219 \\
Dukungan Manajemen Puncak (Dmp) & 0,931 & 0,355 \\
\hline Sumber: Data diolah, 2018 & &
\end{tabular}

Tabel 9 menunjukkan hasil analisis regresi linier berganda dengan rumus:

$$
\text { Kin }=\alpha+\beta_{1} P e l+\beta_{2} K e m+\beta_{3} D m p+e .
$$

Dimana:

Kin $\quad=$ Kinerja Individual

$\alpha=$ Bilangan konstan, jika seluruh nilai independen adalah nol

$\beta_{1} ; \beta_{2} ; \beta_{3} \quad=$ Koefisien Regresi Variabel Pel; Kem; Dmp

Pel $\quad=$ Pelatihan

Kem $\quad=$ Kemampuan teknik pemakai

Dmp = Dukungan manajemen puncak

$e \quad=$ Residual error atau variabel pengganggu 
Tabel 9.

Hasil Analisis Regresi Linier Berganda

\begin{tabular}{|c|c|c|c|c|c|}
\hline \multirow{2}{*}{ Model } & \multicolumn{2}{|c|}{$\begin{array}{l}\text { Unstandardized } \\
\text { Coefficients }\end{array}$} & $\begin{array}{l}\text { Standardized } \\
\text { Coefficients }\end{array}$ & \multirow{2}{*}{$\mathrm{T}$} & \multirow{2}{*}{ Sig. } \\
\hline & $\mathrm{B}$ & $\begin{array}{l}\text { Std. } \\
\text { Error }\end{array}$ & Beta & & \\
\hline (Constant) & 2,744 & 1,074 & & 2,556 & 0,013 \\
\hline Pelatihan (Pel) & 0,207 & 0,068 & 0,243 & 3,029 & 0,003 \\
\hline $\begin{array}{l}\text { Kemampuan Teknik Pemakai } \\
\text { SIA (Kem) }\end{array}$ & 0,515 & 0,078 & 0,549 & 6,603 & 0,000 \\
\hline $\begin{array}{l}\text { Dukungan Manajemen Puncak } \\
\text { (Dmp) }\end{array}$ & 0,171 & 0,072 & 0,192 & 2,37 & 0,020 \\
\hline$R$ Square & 0,855 & & & & \\
\hline F Hitung & 149,859 & & & & \\
\hline Signifikansi F & 0,000 & & & & \\
\hline
\end{tabular}

Berdasarkan hasil penelitian tersebut, maka model regresi linier berganda adalah:

$$
\text { Kin }=2,744+0,207 \mathrm{Pel}+0,515 \mathrm{Kem}+0,171 \mathrm{Dmp}+e
$$

Penjelasan dari persamaan regrsi tersebut yaitu nilai konstanta sebesar 2,744, menunjukkan apabila Pel, Kem dan Dmp bernilai 0, maka kinerja individual sebesar 2,744. Nilai Pel sebesar 0,207, berarti jika Pel meningkat 1 satuan maka kinerja individual meningkat sebesar 0,207. Nilai Kem sebesar 0,515 berarti jika Kem meningkat satu satuan maka kinerja individual meningkat sebesar 0,515. Dmp sebesar 0,171 berarti jika Dmp meningkat satu satuan maka kinerja individual meningkat sebesar 0,171 .

Kemampuan teknik pemakai SIA memiliki koefisien regresi tertinggi yaitu sebesar 0,515. Ini berarti dari ketiga variabel bebas yang digunakan, variabel kemampuan teknik pemakai SIA yang paling mempengaruhi variabel terikat yaitu kinerja individual. 
Ni Made Ayu Nita Adityantari dan I Ketut Yadnyana. Pengaruh ...

Tabel 9 menunjukkan bahwa nilai signifikansi uji $\mathrm{F}$ yaitu sebesar 0,000 yang lebih kecil dari 0,05 . Hal ini berarti bahwa model yang digunakan dalam penelitian ini layak untuk digunakan.

Salah satu alat untuk mengukur ketepatan atau kesesuaian (goodness of fit) garis regresi terhadap datanya adalah koefisien deternimasi. Penelitian ini menggunakan nilai $R$ Square untuk menghindari bias terhadap jumlah variabel bebas. Berdasarkan Tabel 9 nilai $R$ Square adalah sebesar 0,855yang berarti bahwa 85,5 persen variabel kinerja individual dapat dijelaskan oleh variabel pelatihan, kemampuan teknik pemakai SIA dan dukungan manajemen puncak dan dipengaruhi oleh faktor-faktor lain yang tidak termasuk dalam model penelitian ini.

Tabel 9 menunjukan bahwa nilai signifikansi variabel pelatihan lebih kecil dari 0,05 yaitu 0,003 maka $\mathrm{H}_{1}$ diterima dan $\mathrm{H}_{0}$ ditolak. Pengaruh positif antara pelatihan dengan kinerja individual berarti semakin sering karyawan mengikuti program pelatihan maka kinerja individual akan meningkat.

Penelitian ini didukung oleh teori TAM yang menjelaskan bahwa perilaku personal dipengaruhi oleh dua hal dalam menggunakan dan menerima teknologi, yaitu usefulness atau kemanfaatan dan ease of use atau kemudahan penggunaan yang kemudian dapat mempengaruhi kinerja (Eka, 2017). Rouibah et al. (2009) mengungkapkan bahwa ada tidaknya pelatihan adalah dasar dari persepsi ease of use atau kemudahan penggunaan yang kemudian akan berpengaruh terhadap kepuasan dari pengguna dan akan memberikan dampak yang positif pada kinerja karyawan. Hasil penelitian ini sesuai dengan hasil penelitian yang dilakukan oleh 
Roubiah et al. (2009), Dwijayanthi dan Dharmadiaksa (2013) dan Medina et al. (2014) yang menemukan bahwa pelatihan berpengaruh positif dan signifikan terhadap kinerja individu pengguna sistem informasi akuntansi. Dengan diadakannya pelatihan secara rutin, karyawan dapat meningkatkan kemampuannya dalam melakukan pekerjaan yang kemudian meningkatkan kinerjanya. Tujuan lain dari pletihan secara berkelanjutan dan rutin adalah memberikan karyawan pengetahuan baru yang dapat meningkatkan penguasaan karyawan tersebut terhadap teknologi yang digunakan.

Tabel 9 menunjukan bahwa nilai signifikansi variabel teknik pemakai SIA lebih kecil dari 0,05 yaitu 0,000 maka $\mathrm{H}_{1}$ diterima dan $\mathrm{H}_{0}$ ditolak. Pengaruh positif antara teknik pemakai SIA terhadap kinerja individual berarti semakin baik kemampuan teknik pemakai SIA maka kinerja akan meningkat.

Penelitian ini didukung oleh teori TAM yang menjelaskan bahwa perilaku personal dipengaruhi oleh dua hal dalam menggunakan dan menerima teknologi, yaitu usefulness atau kemanfaatan dan ease of use atau kemudahan penggunaan yang kemudian dapat mempengaruhi kinerja (Surendran, 2012). Pemahaman dari karyawan mengenai bagaimana menggunakan dan mengaplikasikan teknologi sangat diperlukan agar informasi yang dihasilkan dari teknologi yang digunakan dapat dijaadikan dasar untuk pengambilan keputusan. Persepsi dari kemudahan penggunaan disini dimaksud adalah berhubungan dengan teknik personal dari pengguna. Pernytaan ini sesuai dengan pernyataan dalam teori TAM. Semakin baik kemempuan teknik personal dari pengguna maka pengguna akan merasa 
Ni Made Ayu Nita Adityantari dan I Ketut Yadnyana. Pengaruh ...

adanya kemudahan dalam menggunakan teknologi yang kemudian berdampak pada mengningkatnya kinerja dari karyawan. (Turnip, 2017).

Hasil penelitian ini sesuai dengan penelitian yang dilakukan oleh Zaim et al. (2013), Alannita (2014) dan Widyasari (2015) yang menemukan bahwa kemampuan teknik pemakai sistem informasi akuntansi berpengaruh positif pada kinerja individual karyawan. Kecukupan dari kemampuaan teknik personal pengguna teknologi akan berdampak pada operasional dari Sistem Informasi Akuntansi. pengguna yang memiliki kemampuan teknik personal yang cukup akan memaksimalkan operasi dari Sistem Informasi Akuntansi.

Tabel 9 menunjukan bahwa nilai signifikansi variabel dukungan manajemen puncak lebih kecil dari 0,05 yaitu 0,002 maka $\mathrm{H}_{1}$ diterima dan $\mathrm{H}_{0}$ ditolak. Pengaruh positif antara teknik pemakai SIA terhadap kinerja individual berarti semakin banyak dukungan dari manajemen puncak maka kinerja akan meningkat.

Penelitian ini didukung oleh teori Keyakinan Diri, dimana salah satu cara untuk meningkatkan keyakinan diri adalah dengan memberikan dukungan (Bandura dalam Wirawan, 2016). Dukungan dari manajemen puncak dapat diberikan dengan berbagai cara salah satunya adalah manajemen puncak memberikan sumber daya yang memadai dan diperlukan bagi karyawan dan jungaa menyediakan program pelatihan bagi karyawan yang menggunakan sistem. Dengan adanya dukungan yang diberikan oleh manajemen puncak, karyawan akan lebih memiliki kepercayaan diri terhadap keahlian yang dimiliki sehingga karyawan dapat menggunakan Sistem Informasi Akuntansi secara maksimal. 
Hasil penelitian ini sesuai dengan hasil penelitian yang dilakukan oleh Widyasari (2015), Wirawan (2016) dan Eka (2017) yang menemukan adanya hubungan yang positif antara dukungan manajemen puncak dengan kinerja individual karyawan. Dukungan dari manajemen puncak dapat diberikan dengan berbagai cara salah satunya adalah manajemen puncak memberikan sumber daya yang memadai dan diperlukan bagi karyawan dan jungaa menyediakan program pelatihan bagi karyawan yang menggunakan sistem. Dengan adanya dukungan yang diberikan oleh manajemen puncak, karyawan akan lebih memiliki kepercayaan diri terhadap keahlian yang dimiliki sehingga karyawan dapat menggunakan Sistem Informasi Akuntansi secara maksimal.

\section{SIMPULAN}

Pelatihan berpengaruh positif pada kinerja individual pengguna SIA di PT. BPR Bank Kertiawan. Hal ini menunjukkan bahwa semakin sering pelatihan yang diikuti oleh karyawan, maka kinerja individual akan semakin tinggi.

Kemampuan teknik pemakai sistem informasi akuntansi memiliki pengaruh yang positif pada kinerja individual pengguna SIA di PT. BPR Bank Kertiawan.

Dukungan manajemen puncak memiliki pengaruh yang positif pada kinerja individual pengguna SIA di PT. BPR Bank Kertiawan. Hal ini menunjukkan bahwa semakin tinggi tingkat dukungan manajemen puncak PT. BPR Bank Kertiawan, maka kinerja individual akan semakin tinggi. 


\section{REFRENSI}

Alannita, N. P., \& Suaryana, I. G. N. A. (2014). Pengaruh Kecanggihan Teknologi Informasi, Partisipasi Manajemen, Dan Kemampuan Teknik Pemakai Sistem Informasi Akuntansi Pada Kinerja Individu. E-Jurnal Akuntansi Universitas Udayana, 1(Issn: 2302-8556), 33-45. Https://Doi.Org/10.4018/978-1-60566996-0.Ch011

Arsiningsih, N. L. P. F., Diatmika, P. G., \& Darmawan, N. A. S. (2015). Pengaruh Penggunaan Teknologi Informasi, Efektivitas Sistem Informasi Akuntansi, Kepercayaan Atas Sistem Informasi Akuntansi, Sistem Pengendalian Intern Terhadap Kinerja Karyawan Pada Bank Perkreditan Rakyat Di Kabupaten Buleleng Dan Bangli. S1 Akuntansi Universitas Pendidikan Ganesha Jurusan Akuntansi Program S1, 3(1).

Artha, N. L. A. D. (2016). Pengaruh Efektivitas Sistem Informasi Akuntansi, Pemanfaatan Teknologi Informasi Dan Kemampuan Teknis Pemakai Sistem Informasi Akuntansi Terhadap Kinerja Individu Pada Koperasi Simpan Pinjam Di Kabupaten Karangasem. Fakultas Ekonomi Dan Bisnis Universitas Udayana.

Bodnar, G. H., \& Hopwood, W. S. (2006). Sistem Informasi Akuntansi Edisi 9. Yogyakarta: Andi.

Bunga, M. (2014). Pengaruh Kemampuan Teknik Personal, Dukungan Manajemen Puncak, Program Pelatihan Dan Pendidikan Terhadap Kinerja Sistem Informasi Akuntansi Pada Pt. Kerta Rajasa Raya. Upn "Veteran" Jawa Timur.

Dunggio, I. C. N. (2015). Pengaruh Faktor-Faktor Sistem Informasi Terhadap Kinerja Sistem Informasi Akuntansi, 1-49.

Dwijayanthi, D. M., \& Dharmadiaksa, I. B. (2013). Pengaruh Insentif, Tingkat Pendidikan, Pelatihan Dan Pengalaman Kerja Terhadap Kinerja Individu Pengguna Sistem Informasi Akuntansi Skpd Dispenda Kota Denpasar. EJurnal Akuntansi Universitas Udayana, 4(2), 332-344. Https://Doi.Org/10.1095/Biolreprod.110.085282

Fitri, N. (2008). Faktor-Faktor Yang Mempengaruhi Kinerja Sistem Informasi Akuntansi Pada Perusahaan Farmasi Di Medan. Child Development, 72(1), 187-206. Https://Doi.Org/10.1007/S13398-014-0173-7.2 
Ghozali, I. (2016). Aplikasi Analisis Multivariete Dengan Program Ibm Spss 23. Semarang: Badan Penerbit Universitas Diponegoro.

Hendra, D., Setiawanta, Y., \& Septriana, I. (2014). Analisis Pengaruh Keterlibatan Pemakai Dalam Pengembangan Sistem Informasi, Dukungan Manajemen Puncak, Dan Formalisasi Pengembangan Sistem Informasi Terhadap Kinerja Sistem Informasi Akuntansi Pada Pt. Bank Jateng Cabang Ungaran. Jurnal Jurusan Akuntansi Fakultas Ekonomi Universitas Dian Nuswantoro Semarang, Hal 1-18.

Komara, A. (2005). Analisis Faktor-Faktor Yang Mempengaruhi Kinerja Sistem Informasi Akuntansi Drs. Acep Komara, Se., Msi. Universitas Swadaya Gunung Jati Cirebon. Jurnal Sna 8, (September), 15-16.

Lee, Y., Kozar, K. A., \& Larsen, K. R. T. (2003). The Technology Acceptance Model: Past, Present, And Future. Communications Of The Association For Information Systems, 12(1). Https://Doi.Org/10.17705/1cais.01250

Mangkuprawira, T. S. (2003). Manajemen Sumber Daya Manusia Strategik. Jakarta: Ghaflia Indonesia.

Medina, J., Jiménez, D. K., Mora, A., \& Ábrego, M. S. D. (2014). Training In Accounting Information Systems For Users 'Satisfaction And Decision Making (Training), 5(7), 134-145.

Mooney, A., Mahoney, M., \& Wixom, B. (2008). Achieving Top Management Support In Strategi Technology Initiatives. Howe School Alliance For Technology Management, 12(2), 1-3.

Mulyadi. (2016). Sistem Akuntansi Edisi 4. Jakarta: Salemba Empat.

Ochoti, G. N., Maronga, E., Muathe, S., Nyabwanga, N. R., \& Ronoh, P. K. (2012). Factors Influencing Employee Performance Appraisal System: A Case Of The Ministry Of State For Provincial Administration \& Internal Security, Kenya. International Journal Of Business And Social Science, 3(20), 37-46. Https://Doi.Org/10.5296/Jpag.V2i4.2751

Robbins, S. P., Decenzo, D. A., \& Coulter, M. K. (2008). Fundamentals Of Management: Essential Concepts And Applications. Upper Saddle River, Nj: Pearson Prentice Hall.

Romney, M. B., \& Steinbart, P. J. (2014). Sistem Informasi Akuntansi. Jakarta: Salemba Empat. 
Rouibah, K., Hamdy, H. I., \& Al-Enezi, M. Z. (2009). Effect Of Management Support, Training, And User Involvement On System Usage And Satisfaction In Kuwait. Industrial Management And Data Systems, 109(3), 338-356. Https://Doi.Org/10.1108/02635570910939371

Sarastini, N. P. E., \& Suardikha, I. M. S. (2017). Pengaruh Pelatihan Dan Pendidikan, Dukungan Manajemen Puncak Dan Kemampuan Teknik Pemakai Sia Pada Kinerja Individual. Jurnal Akuntansi Universitas Udayana, 20(2), 1476-1503. Https://Doi.Org/Https://Doi.Org/10.24843/Eja.2017.V20.I02.P22

Simamora, H. (2007). Manajemen Sumber Daya Manusia. Yogyakarta.

Sugiyono. (2017). Metode Penelitian Bisnis. Bandung: Alfabeta.

Surendran, P. (2015). Thermal And Catalytic Slow Pyrolysis Of Calophyllum Inophyllum Fruit Shell. Bioresource Technology, 193, 463-468. Https://Doi.Org/10.1016/J.Biortech.2015.06.132

Sutadji, I. M., \& Hariyanti, V. S. (2016). Pengaruh Insentif, Tingkat Pendidikan, Pelatihan Dan Pengalaman Kerja Terhadap Kinerja Individu Pengguna Sistem Informasi Akuntansi Skpd Dispenda Kota Balikpapan. Jurnal Geo Ekonomi, 7(2), 135-148.

Uu No. 10 Tahun 1998. (N.D.). Retrieved From Https://Jdih.Kemenkeu.Go.Id/Fulltext/1998/10tahun 1998uu.Htm

Widyasari, H., \& Suardikha, I. M. S. (2015). Pengaruh Kemampuan Teknik Pemakai, Efektivitas Sia, Dukungan Manajemen Puncak, Lingkungan Kerja Fisik Pada Kinerja Individual, 678-697.

Wilkinson, J. W., \& Cerrulo, M. J. (2000). Accounting Information System Essential Concept And Application (Fourth Edi). Usa: John Wiley \& Sons, Inc.

Wirawan, S. B., \& Suardikha, I. M. S. (2016). Faktor-Faktor Yang Mempengaruhi Kinerja Individual Pada Bank Perkreditan Rakyat Di Kabupaten Badung. EJurnal Akuntansi Universitas Udayana, 17(3), 2302-8556. Retrieved From Https://Ojs.Unud.Ac.Id/Index.Php/Akuntansi/Article/View/24557

Wulandari, A. A. . P. S. (2016). Pengaruh Dukungan Manajemen Puncak, Keterlibatan Pengguna, Program Pelatihan Terhadap Kinerja Sia Pada Bpr Di Kediri. Fakultas Ekonomi Dan Bisnis Universitas Udayana. 
Zaim, H., Yasar, M. F., \& Omer Faruk Unal. (2013). Analyzing The Effects Of Individual Competencies On Performance: A Field Study In Services Industries In Turkey. Journal Of Global Strategic Management, 7(2), 67-77.

Zein, M. . (2012). Analisis Faktor-Faktor Yang Memengaruhi Kinerja Pemakai Sistem Informasi Akuntansi Pada Perusahaan Asuransi Di Wilayah Bandung. 